\title{
43. OXYGEN ISOTOPE STRATIGRAPHY AND PALEOCLIMATOLOGY OF SOUTHWESTERN ATLANTIC QUATERNARY SEDIMENTS (RIO GRANDE RISE) AT DEEP SEA DRILLING PROJECT SITE 5171
}

\author{
C. Vergnaud Grazzini and M. Grably, Laboratoire de Géologie Dynamique, Université Pierre et Marie Curie, \\ 75230 Paris Cedex 05, France \\ and \\ C. Pujol and J. Duprat, Université de Bordeaux I, Département de Géologie et Océanographie, \\ 33405 Talence, France
}

\begin{abstract}
Oxygen and carbon isotope analyses were performed on monospecific or mixed-species samples of benthic foraminifers, as well as on the planktonic species Globigerinoides ruber from a 24 -m hydraulic piston core raised on the western flank of the Rio Grande Rise, at DSDP Site $517\left(30^{\circ} 56.81^{\prime} \mathrm{S}\right.$ and $38^{\circ} 02.47^{\prime} \mathrm{W}$, water depth $\left.2963 \mathrm{~m}\right)$ in the southwestern Atlantic. This site is presently located in the core of North Atlantic Deep Water (NADW). This is the first long isotopic record of Quaternary benthic foraminifers; it displays at least 30 isotopic stages, 25 of them readily correlated with the standard sequence of Pacific Core V28-239. The depths of both the Bruhnes/Matuyama boundary and the Jaramillo Event based on oxygen isotope stratigraphy agree well with paleomagnetic results. Quaternary faunal data from this part of the Atlantic are dated through isotopic stratigraphy and partially contradict data previously published by Williams and Ledbetter (1979). There was a substantial increase in the size of the earth's major ice sheets culminating at Stage 22 and corresponding to a $1 \%$ progressive increase of $\delta^{18} \mathrm{O}$ maximal values. Further, ice volume-induced isotopic changes were not identical for different glacial cycles. Oxygen and carbon isotope analyses of benthic foraminifers show that during Pleistocene glacial episodes, NADW was cooler than today and that Mediterranean outflow might still have contributed to the NADW sources. The comparison of coiling ratio changes of Globorotalia truncatulinoides with planktonic and benthic oxygen isotope records shows that there might have been southward excursions of the Brazil Current during the Pleistocene, perhaps related to Antarctic surface water surges. The question of the location of NADW sources during glacial maxima remains open.
\end{abstract}

\section{INTRODUCTION}

For the Pleistocene, the stratigraphically longest detailed oxygen isotopic records from the oceans extend to sediments about 2.3 Ma old from Pacific Core V28-239 (Shackleton and Opdyke, 1976) and equatorial Atlantic Core V16-205 (van Donk, 1976). They indicate that Pleistocene-like glacial events occurred well below the horizon stratigraphically equivalent to the base of the Quaternary, as it is defined in Italy. Further, Shackleton and Opdyke (1977) extended the isotopic record and paleomagnetic analyses back to more than $3.5 \mathrm{Ma}$ based on equatorial Pacific Core V28-179. These authors identified the onset of quasi-cyclic glacial-interglacial fluctuations at about 3.2 Ma and demonstrated that the scale of glaciations increased about $2.5 \mathrm{Ma}$. Oxygen and carbon isotopic determinations on benthic foraminifers at DSDP Site 397 permitted Shackleton and Cita (1979) to reconstruct the history of isotopic variations through the past $7 \mathrm{Ma}$ with a sampling resolution around $20,000 \mathrm{yr}$. These authors concluded that the temperature of Atlantic Ocean deep water has remained rather constant and that the oxygen isotopic record reflected only oscillations in the volume of the earth's major ice sheets. Variations in $\delta^{13} \mathrm{C}$ for the Pleistocene were also interpreted in terms of continental biomass fluctuations.

\footnotetext{
${ }^{1}$ Barker, P. F., Carlson, R. L., Johnson, D. A., et al., Init. Repts. DSDP, 72: Washing. ton (U.S. Govt. Printing Office).
}

Oxygen and carbon isotope analyses presented here were performed on benthic and planktonic foraminifers from a 24-m long hydraulic piston core raised on the western flank of the Rio Grande Rise, at DSDP Site 517 $\left(30^{\circ} 56.81^{\prime} \mathrm{S}\right.$ and $38^{\circ} 02.47^{\prime} \mathrm{W}$, water depth $\left.2963 \mathrm{~m}\right)$ in the southwestern Atlantic (Fig. 1). This site is presently situated in the core of the North Atlantic Deep Water (NADW): $\mathrm{t}=2.4^{\circ} \mathrm{C}$ and $\mathrm{S}=34.9 \%$.

The results lead to the identification of 30 isotopic stages and provide evidence of an increase in continental ice sheets in the early Pleistocene before the time of the Jaramillo Event.

\section{METHOD}

Stable isotope analyses were made, whenever possible, at $10-\mathrm{cm}$ intervals in the samples previously used for micropaleontologic and biostratigraphic studies (Pujol and Duprat, this volume).

Benthic and planktonic foraminifers were selected for isotopic analyses from the $>150 \mu \mathrm{m}$ fraction after sieving and ultrasonic cleaning. Carbon dioxide was released from the carbonate by reaction with $100 \%$ orthophosphoric acid at $50^{\circ} \mathrm{C}$ in an oven and analyzed on a VG Micromass $602 \mathrm{C}$ mass spectrometer. Results are expressed relative to the PDB standard using the $\delta$ notation defined by the relationships:

$$
\delta^{18} \mathrm{O}=\left[\frac{{ }^{18} \mathrm{O} /{ }^{16} \mathrm{O} \text { sample }}{{ }^{18} \mathrm{O} /{ }^{16} \mathrm{O} \text { standard }}-1\right] \times 1000 .
$$

A similar equation was used for $\delta^{13} \mathrm{C}$.

Working reference gas was extracted from a white marble and calibrated against standard NBS 20 limestone, which was treated in the same way as the other samples. The standard gave $\delta^{18} \mathrm{O}=+1.91$ and $\delta^{13} \mathrm{C}=+3.41$ versus NBS 20 . 


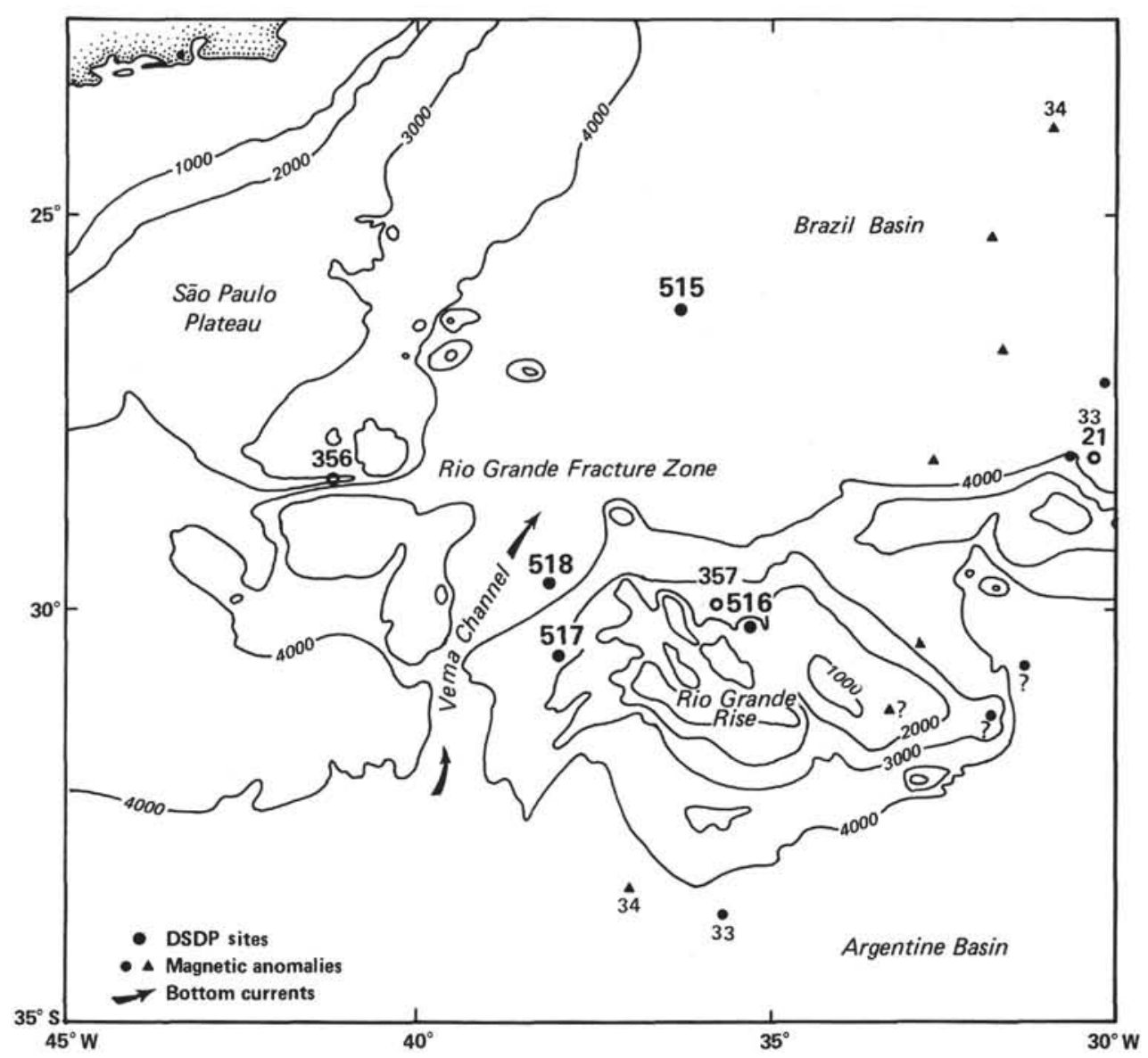

Figure 1. Location of Sites 515, 516, 517, and 518 on the Rio Grande Rise and in the Brazil Basin.

The standard deviation $(\sigma)$ calculated from 50 repeated analyses of different samples of the same carbonate powder, calibrated against NBS 20 was $\sigma=0.10$ for $\delta^{18} \mathrm{O}$ and $\sigma=0.06$ for $\delta^{13} \mathrm{C}$. The standard deviation for 30 analyses of the same foraminiferal species in recent surface sediment was $\sigma=0.15$ for $\delta^{18} \mathrm{O}$. The average difference between duplicate or triplicate foraminiferal analyses is around $0.15 \%$ for $\delta^{18} \mathrm{O}$. The main sources of uncertainty are laboratory errors, isotopic variability among specimens, and analytic precision. Another source of uncertainty is introduced in the estimation of the factor by which analyses for different species may be corrected for departure from isotopic equilibrium.

\section{BENTHIC FORAMINIFERS}

Because analyses cannot be performed on less than $0.5 \mathrm{mg}$ of calcium carbonate, it was not possible to analyze monospecific samples of benthic foraminifers throughout the cores. Species-dependent departure from isotopic equilibrium for different species and for mixedspecies assemblages are not immediately comparable (Duplessy et al., 1970). Five genera were available throughout most of the cores: Uvigerina spp., Planulina spp., Cibicidoides spp., Pyrgo spp., and Cassidulina spp. Departures from isotopic equilibrium for these taxa have been estimated by various authors (Belanger et al., 1981; Boersma and Shackleton, 1977; Graham et al., 1981; Shackleton, 1974, 1977; Shackleton and Cita, 1979; Streeter and Shackleton, 1979; Vergnaud Grazzini, 1973; Vincent et al., 1981; Vinot-Bertouille and Duplessy, 1973; Wefer and Berger, 1980; Woodruff et al., 1980). Such estimates may not always be similar for the different authors. Our results were normalized to Uvigerina, using the following corrections (Duplessy, personal communication, 1982):

\begin{tabular}{lrr}
\hline \multicolumn{1}{c}{ Species } & $\Delta^{18} \mathrm{O}$ & \multicolumn{1}{c}{$\Delta^{13} \mathrm{C}$} \\
\hline Uvigerina spp. & 0.00 & 0.00 \\
Pyrgo spp. & +0.50 & +0.90 \\
Planulina spp. & & \\
$\quad$ and Cibicidoides spp. & -0.64 & +0.90 \\
Cassidulina spp. & 0.00 & 0.00 \\
\hline
\end{tabular}

where $\Delta^{18} \mathrm{O}=\delta^{18} \mathrm{O}$ spp. $-\delta^{18} \mathrm{O}_{\text {Uvigerina }}$ and $\Delta^{13} \mathrm{C}=\delta^{13} \mathrm{C}$ spp. $\delta^{13} C_{\text {Uvigerina }}$

Most benthic data in this study are for mixed-species samples. Because all calcitic species have been shown to display ${ }^{18} \mathrm{O}$ disequilibria accounting for a $\delta^{18} \mathrm{O}$ ranging from -0.38 to $-1.02 \%$ (Graham et al., 1981) and $U v i$ gerina and Pyrgo are the closest to ${ }^{18} \mathrm{O}$ equilibrium, we expect mixed-species samples to deviate less than $-0.6 \%$ from Uvigerina. Furthermore, because carbon disequilibrium is relatively high for Uvigerina species $(-1.65 \%)$, we expect mixed species to display $\delta^{13} \mathrm{C}$ values closer to equilibrium values than Uvigerina. Our analyses show that $\delta^{13} \mathrm{C}$ of mixed species are on the average higher by $+0.9 \%$ than $\delta^{13} \mathrm{C}$ of Uvigerina. 


\section{PLANKTONIC FORAMINIFERS}

The planktonic species Globigerinoides ruber was abundant enough to be analyzed throughout the core. Isotopic disequilibrium has been inferred for this species for both oxygen and carbon (Shackleton et al., 1976; Shackleton and Vincent, 1978; Vergnaud Grazzini, 1976). Assuming that this isotopic departure remained constant through time, this shallow-dwelling species may be used for paleotemperature reconstructions in surface waters.

The results are reported in the curves in Figures 2 and 3. Data points normalized relative to the oxygen isotopic ratio of Uvigerina are represented by dots, and uncorrected results (from mixed-species samples) by circles. Values are listed in Appendices A and B at the end of the chapter.

\section{OXYGEN ISOTOPE STRATIGRAPHY}

Emiliani $(1955,1966)$ numbered from 1 to 15 the stages that he recognized in the oxygen isotope records obtained for planktonic foraminifers in sediments cored from the Caribbean Sea and from the Atlantic Ocean. Also analyzing planktonic foraminifers, Shackleton and Opdyke $(1973,1976)$ recognized 23 stages in Cores V28238 and V28-239. As a result of our analysis, we present the first long isotopic record of Quaternary benthic foraminifers (Fig. 2). The curve shows well-defined isotopic stages: at least 30 isotopic stages can easily be recognized in the upper $17 \mathrm{~m}$ of the section drilled at Site 517; this record can be readily correlated with the standard sequence of Pacific Core V28-239, down to Stage 25. The depths of stage boundaries are given in Table 1.

In accordance with this isotopic stratigraphy, we propose a few age estimates.

1) Location of the Bruhnes/Matuyama boundary at the transition from Stage 19 to Stage 20 (Berggren et al.,

Table 1. Isotopic stage boundaries in the Quaternary sequence of Hole 517.

\begin{tabular}{ccc}
\hline $\begin{array}{c}\text { Stage } \\
\text { boundary }\end{array}$ & $\begin{array}{c}\text { Core-section } \\
\text { (level in cm) }\end{array}$ & Terminations \\
\hline $5-6$ & $1-1,80 \longrightarrow$ II \\
$6-7$ & $1-1,120$ \\
$7-8$ & $1-2,0$ \\
$8-9$ & $1-2,60$ \\
$9-10$ & $2-1,50 \longrightarrow$ III \\
$10-11$ & $2-1,100$ \\
$11-12$ & $2-2,20$ \\
$12-13$ & $2-2,80$ \\
$15-16$ & $3-2,30 \longrightarrow$ IV \\
$16-17$ & $3-2,60$ \\
$19-20$ & $4-2,5$ \\
$20-21$ & $4-2,60$ \\
$21-22$ & $4-3,0$ \\
$22-23$ & $4-3,70$ \\
$25-26$ & $5-1,85$ \\
$26-27$ & $5-2,15$ \\
$27-28$ & $5-2,35$ \\
$28-29$ & $5-2,70$ \\
\hline
\end{tabular}

Note: Terminations from Broecker and van Donk (1970).
1980) permits assignment of about $730,000 \mathrm{Ma}$ to the level of Sample 517-4-2, $10 \mathrm{~cm}$. One may calculate an average sedimentation rate of $1-3 \mathrm{~cm}$ per thousand years for the upper part of the sequence.

2) The Jaramillo Event should bracket Isotopic Stage 24 , therefore an age of about $900,000 \mathrm{yr}$. is assigned to the Interval $517-4-3,100-150 \mathrm{~cm}$. This latter result is in good agreement with the position of this event proposed by Hamilton and Suzymov (this volume).

Paleontologic events can also be dated through the isotopic stratigraphy proposed for Site 517 . Specifically these events concern the planktonic foraminifers: Globigerina pachyderma, G. eggeri, Globoratalia inflata, G. truncatulinoides, Sphaeroidinella dehiscens, and $G$. crassaformis (Figs. 4 and 5).

The species Globigerina pachyderma displays a first peak of significant increase towards Sample 517-5-2, $20 \mathrm{~cm}$ (Isotopic Stage 26). Relative percentages become higher again at $517-4-2,100 \mathrm{~cm}$, which corresponds to the transition between Isotopic Stages 22 and 21 (Fig. 4). They remain high throughout the upper cores.

Globigerina eggeri disappears during Isotopic Stage 24, between Cores 4 and 5 of Hole 517 .

Globorotalia inflata decreases significantly (from 40 $20 \%$, relative percent of the total fauna) between Isotopic Stages 22 and 21 (Sections 517-4-2, and 517-4-3).

G. truncatulinoides coiling ratios change significantly from predominantly sinistral to predominantly dextral at the transition between Isotopic Stages 21 and 20 (Sample 517-4-2, $60 \mathrm{~cm}$ ).

G. crassaformis decreases in abundance and G. truncatulinoides returns to predominantly sinistral coiling forms at the beginning of Isotopic Stage 15 (Fig. 5).

G. hirsuta appears at Stage 11, which should correspond to an extrapolated age of about $400,000 \mathrm{yr}$. This result apparently contradicts the observations of Williams and Ledbetter (1979) on the Vema Channel. According to these authors, the first appearance datum of this species should be located in Isotopic Stage 7. In fact, in our cores, Isotopic Stage 7 is the time when the relative abundances of $G$. hirsuta significantly increase; this time discrepancy could be related to the particular paleooceanography of the Vema Channel (Ledbetter and Johnson, 1976).

Sphaeroidinella dehiscens disappears progressively starting at Isotopic Stage 13 (Pujol and Duprat, this volume).

The validity of isotopic stratigraphic age assignments to such faunal events, however, should be checked on other Atlantic cores from geographically distinct areas.

\section{GLACIAL CYCLES AND PALEOCEANOGRAPHY}

Figure 2 suggests that the Pleistocene oxygen isotopic record for benthic foraminifers might be divided into two well-characterized episodes. From the base of the Pleistocene, in Section 517-7-1 to Section 517-4-3 (Stage 22 ), glacial cycles are difficult to define, and $\delta^{18} \mathrm{O}$ glacial maximal values increase progressively from less than $+4 \%$ to values higher than $+5 \%$. From Isotopic Stage 22 to Section 517-1-1, maximal isotopic values are extreme (around $+5 \%$ ), and glacial stages are better defined. 
C. VERGNAUD GRAZZINI, M. GRABLY, C. PUJOL, J. DUPRAT

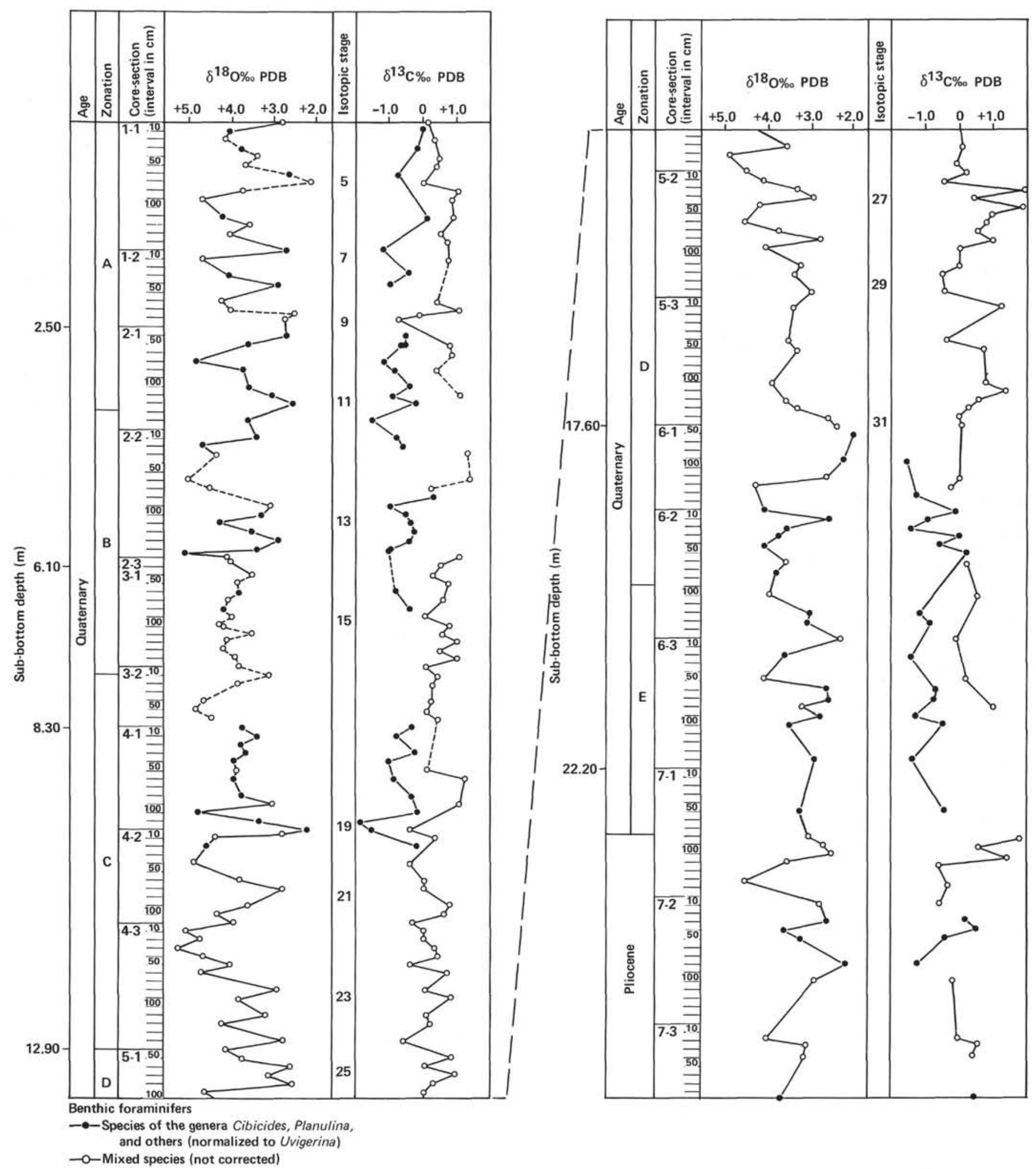

Figure 2. Oxygen and carbon isotopic variations of benthic foraminifers at Hole 517, from the Pliocene through the Quaternary.

\section{The Last Glacial Cycle}

There is a general consensus that at each glacial maximum, sea level was lowered, and that the amplitude of such level changes was about $100 \mathrm{~m}$ for the most recent glaciation. ${ }^{18} \mathrm{O}$-depleted water is removed from the ocean during the buildup of polar ice caps, and the result of its removal is recorded in the oxygen isotopic record preserved in fossil foraminifers (Emiliani, 1955; Olausson, 1965; Shackleton, 1967; Dansgaard and Tauber, 1969; Shackleton and Opdyke, 1973). It is generally thought that bottom water temperature remains approximately 

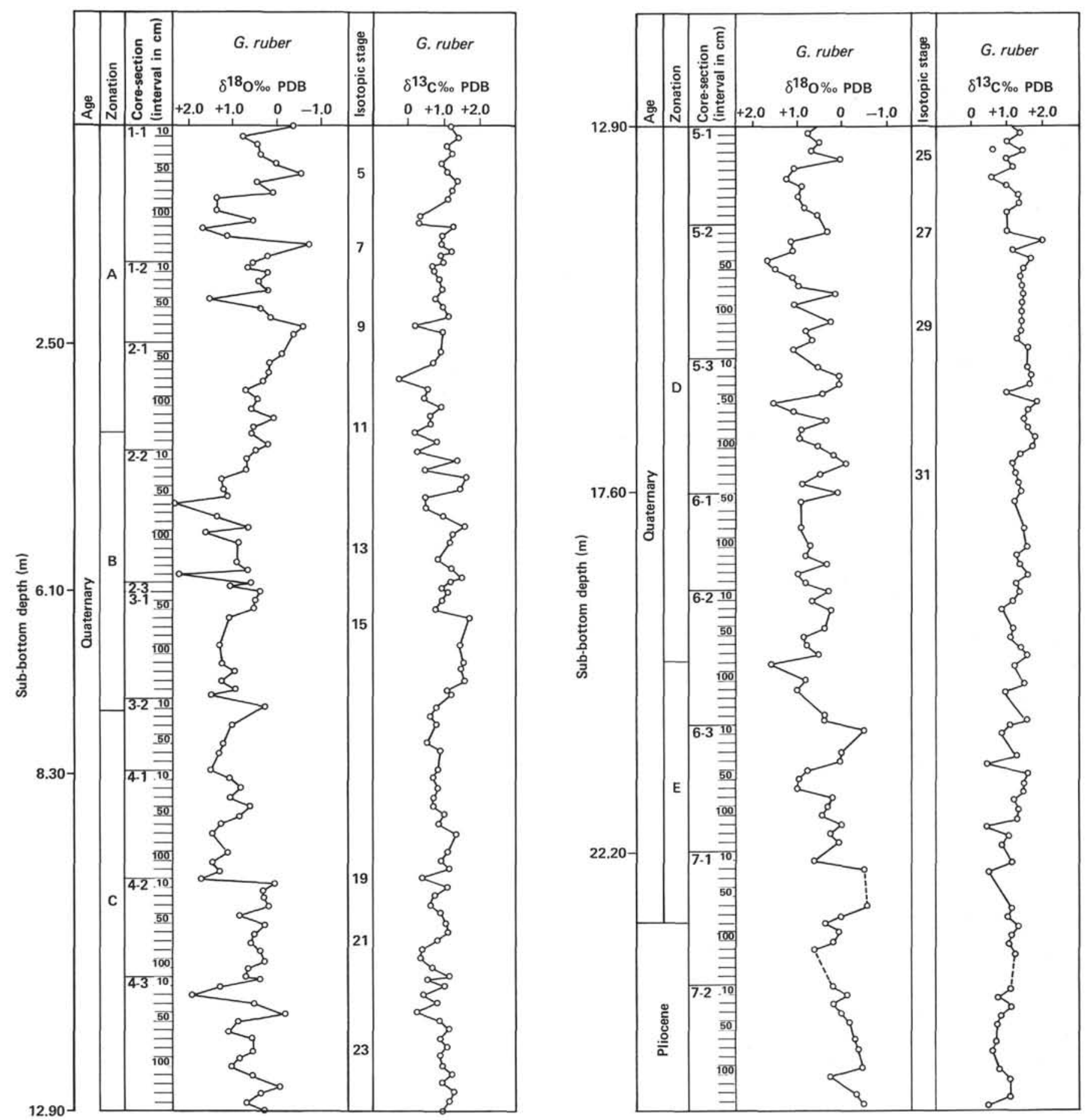

Figure 3. Oxygen and carbon isotopic variations of Globigerinoides ruber at Hole 517, through the Quaternary.

constant throughout glacial cycles. In that case, the major part of AABW originates in the Weddell Sea, where saline-dense water sinks at temperatures close to the freezing point. Thus, in the major part of the oceans, the oxygen isotopic record from benthic foraminifers should only reflect changes in the isotopic composition of sea water. This change is around 1.7\%o (Duplessy et al., 1980); however, at Site 397, Shackleton and Cita
(1979) determined amplitudes of glacial-interglacial ${ }^{18} \mathrm{O}$ variations as high as $1.8 \%$ and even $2 \%$, but these authors did not propose any explanation. Furthermore, Duplessy and others (1980) have shown that in the case of NADW, variations in the amplitude of the isotopic signal preserved in benthic foraminifers between glacial and interglacial stages were around $1.9 \%$ and should also reflect a slight temperature decrease. These authors 


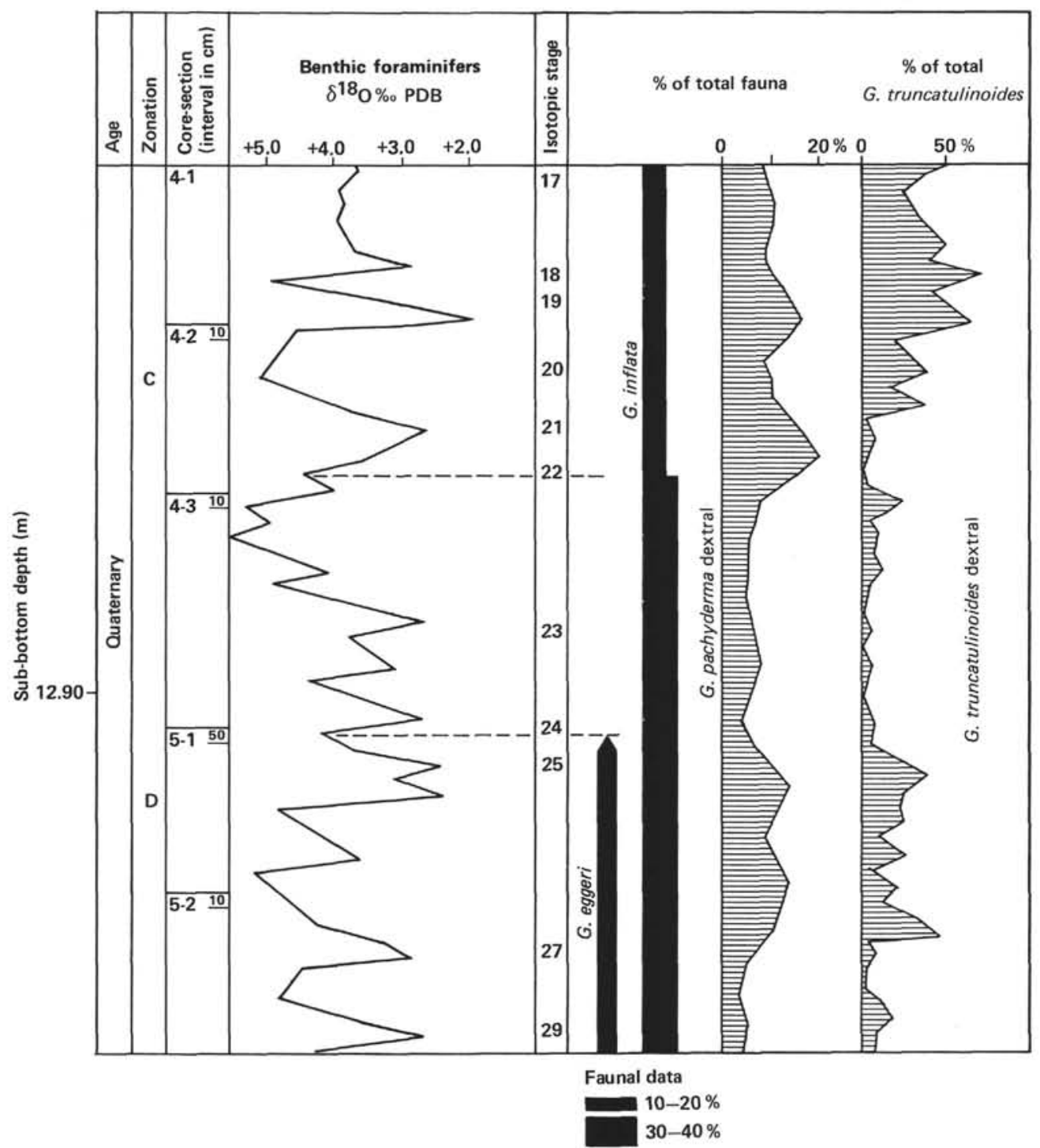

Figure 4. Benthic foraminiferal isotope stratigraphy (from Fig. 2) and Globogerina eggeri, Globorotalia inflata presence data, and Globigerina pachyderma and Globorotalia truncatulinoides coiling ratio changes dated through isotopic stratigraphy.

concluded that cool deep water sources might have existed in the North Atlantic Ocean during the last climatic cycle.

Present-day $\delta^{18} \mathrm{O}$ equilibrium values for calcite formed in the NADW at the location of DSDP Site 517, where temperature is around $2.4^{\circ} \mathrm{C}$ and the oxygen isotopic composition of the water is about $0.12 \%$ (Craig and Gordon, 1965), may be calculated using Shackleton's (1974) temperature scale. That scale is simplified for low temperatures: $\mathrm{t}^{\circ} \mathrm{C}=16.9-4\left(\delta_{\mathrm{c}}-\delta_{\mathrm{w}}\right)$ where $\delta_{\mathrm{c}}$ is the isotopic composition of $\mathrm{CO}_{2}$ extracted from the carbonate and $\delta_{\mathrm{w}}$ is the composition of $\mathrm{CO}_{2}$ in equilibrium with the water at $25^{\circ} \mathrm{C}$, measured relative to the same standard as the $\mathrm{CO}_{2}$ derived from the $\mathrm{CaCO}_{3}$. Using this scale, we find that present-day equilibrium values are around $+3.5 \%$. One should expect therefore, for glacial benthic calcite secreted at the same depth, a $\delta^{18} \mathrm{O}$ around $5.2 \%$. Values of this magnitude do not appear in the last glacial and present interglacial stages (Stages 2 and 1) because of the drilling disturbance of the top of the core. Interglacial minimal $\delta^{18} \mathrm{O}$ values are, furthermore, systematically lower than the calculated value of $3.5 \%$; they average $3 \%$ with some minima around $2.5 \%$, with the exception of Stages 15 and 17 . Converse$\mathrm{ly}, \delta^{18} \mathrm{O}$ maximal values are generally lower than the calculated maximum $5.2 \%$, with the exception of Stage 22 , in which this maximum is reached.

\section{Glacial Cycle and Intensification of Glacial Advance 900,000 Years Ago}

The last glacial cycle (Isotopic Stages 2 and 1) and those cycles corresponding to Isotopic Stages 15 to 17 , 27 to 29 , and isotopic stages older than 30 are marked by peak-to-trough variations of $\delta^{18} \mathrm{O}$ values between glacial maxima and interglacial minima of less than $1.9 \%$. For other glacial-interglacial $\delta^{18} \mathrm{O}$ variations, amplitudes are generally higher and range between 2 and $2.4 \%$. These values can be interpreted in different ways. 


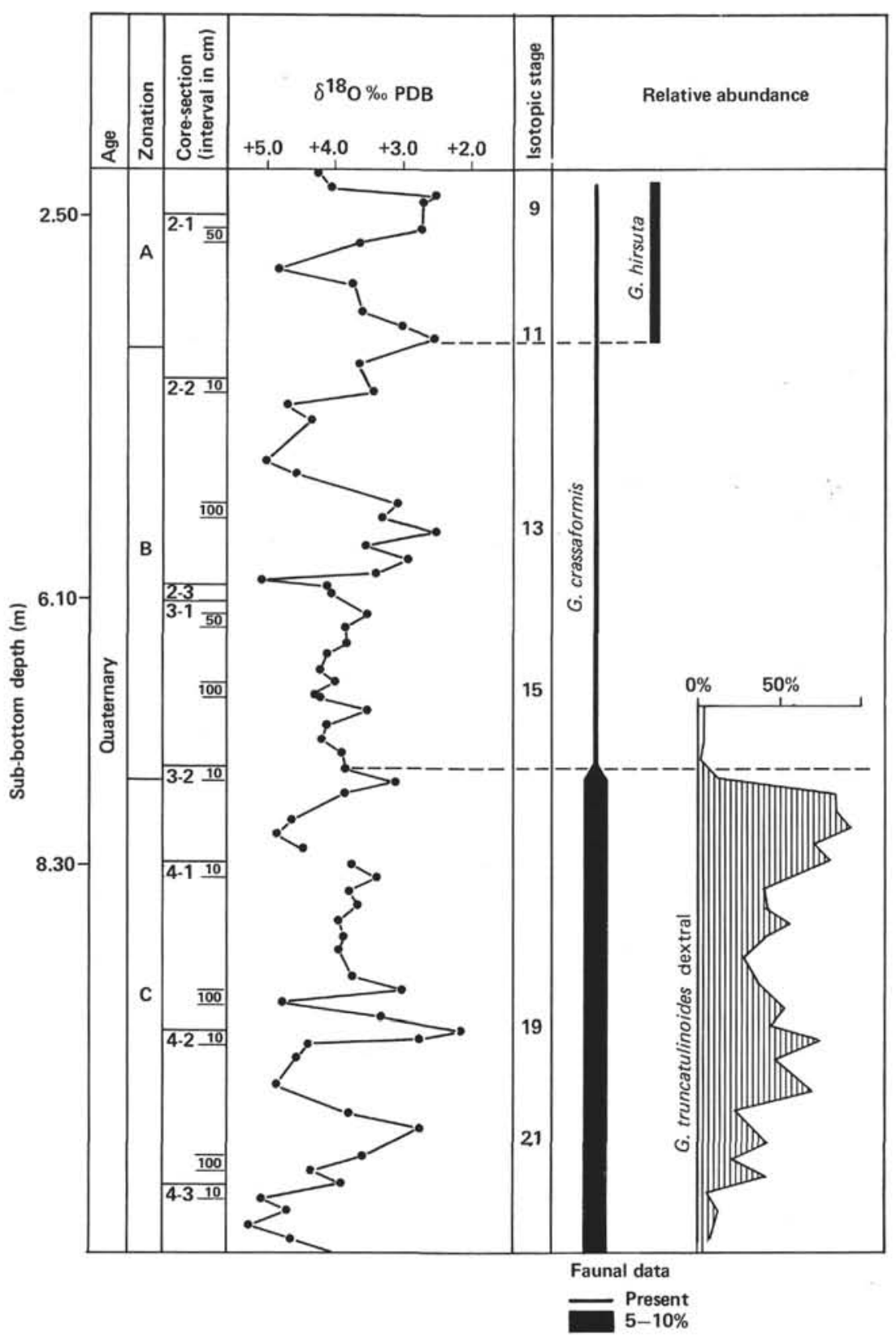

Figure 5. Globorotalia crassaformis and G. hirsuta data and $G$. truncatulinoides coiling ratios and isotopic stratigraphy for mixed species of benthic foraminifers.

Assuming that the continental ice volume variations were similar for all cycles in the late Pleistocene and that the isotopic glacial effect remained the same (and equal to $1.7 \%$ ), the amplitude difference of $0.3 \%$ to $0.7 \%$ observed for some cycles should correspond to a temperature effect. Another explanation could be that the isotopic glacial effect was not exactly the same for the different glacial cycles of the Pleistocene and that continental ice volume variations were not identical. Finally, a third possibility could be that ice $\delta^{18} \mathrm{O}$ values have changed through the Pleistocene (Broecker, 1982).

At the latitude of Site 517, the southward-flowing NADW is characterized by its more oxygen-rich core and high salinity. NADW lies within the density range of the northward-flowing Circumpolar Deep Water
(CPDW) and splits the CPDW into two layers, one above and one below the NADW (Reid et al., 1977). Table 2 shows the temperature and isotopic composition for these water masses.

CPDW is an older, oxygen-poor water, formed largely from lateral exchange with the deeper waters of the Indian and Pacific oceans. CPDW has been long removed from the surface, and its low oxygen content reflects the effects of biologic depletion and oxidation of organic detritus. South of $30^{\circ} \mathrm{S}$, mixing between NADW and CPDW becomes intense and causes large changes in physical parameters.

If 0.3 to $0.7 \%$ of the observed 2 to $2.4 \%$ full-glacial to full-interglacial change in the $\delta^{18} \mathrm{O}$ values for benthic shells reflects a temperature change, it should correspond 
Table 2. Temperature and isotopic composition of different water masses at Site 517.

\begin{tabular}{lccc}
\hline Water mass & $\begin{array}{c}\text { Temperature } \\
\left({ }^{\circ} \mathrm{C}\right)\end{array}$ & $\begin{array}{c}\delta^{18} \mathrm{O} \% \\
\mathrm{SMOW}\end{array}$ & $\begin{array}{c}\delta^{13} \mathrm{C} \% \\
\mathrm{PDB}\end{array}$ \\
\hline NADW & 2.4 & $+0.12 \pm 0.002$ & +0.85 \\
CPDW & $0<\mathrm{t}<1$ & $-0.20,-0.30$ & +0.60 \\
$\quad$ lower layer & $2.6<\mathrm{t}<2.8$ & $-0.20,-0.30$ & +0.60 \\
$\begin{array}{c}\text { CPDW } \\
\quad \text { upper layer }\end{array}$ & & & \\
\hline
\end{tabular}

Note: $\delta^{18} \mathrm{O}$ values are in \% standard mean ocean water; $\delta^{13} \mathrm{C}$ values are in \% PDB standard; NADW $=$ North Atlantic Deep Water; CPDW $=$ Circumpolar Deep Water.

to a temperature effect of 1.2 to $2.8^{\circ} \mathrm{C}$. The lower estimate of $1.2^{\circ} \mathrm{C}$ would imply NADW at temperatures close to those of the CPDW (lower layer). This cooling might be related to a more intense mixing of the two water masses during glacial cycles at this latitude and may suggest an intensification of the Antarctic Circumpolar Current and a larger change in the production rate of AABW. This hypothesis is supported, at least for the most recent glacial cycles, by particle-size analysis of sediments of the Vema Channel (Ledbetter, 1979). These analyses establish an idealized paleovelocity curve of AABW, showing that bottom waters reached a peak velocity during the last glacial stage and part of Isotopic Stage 6. This result contradicts Weyl's theory (1968); however, the causal mechanisms proposed by Weyl may be correct for some glacial periods and not others. Cause and effect relationships between climate and abyssal circulation, moreover, may not have remained constant during the whole Pleistocene.

It is unlikely that NADW was ever cooler than Circumpolar Water (CPW) or that its temperature was less than $0^{\circ} \mathrm{C}$ (unless CPW itself had become cooler during glacial phases). So, the maximum temperature effect expected is $2.4^{\circ} \mathrm{C}$, equivalent to $0.6 \%$ of the isotopic variation. Thus, glacial cycles producing $\delta^{18} \mathrm{O}$ amplitudes higher than $2.3 \%_{0}\left(=1.7 \%_{0}+0.6 \% 0\right)$ might have corresponded to higher oscillations in the volume of the earth's major ice sheets, or slight changes in ice $\delta^{18} \mathrm{O}$ values. These cycles correspond to Isotopic Stages 11 to 13,18 to 20 , and 21 to 23 .

\section{The Lower Pleistocene}

Before Isotopic Stage 22, glacial maxima $\delta^{18} \mathrm{O}$ values increase from +4 to about $+5 \%$. This increase occurs progressively, reaching maximum $\delta^{18} \mathrm{O}$ values during Stage $22(+5.2 \%)$. Shackleton and Opdyke (1976) and Shackleton and Cita (1979) also suggested that glacial extremes earlier than Stage 22 (before the Jaramillo Magnetic Event about 900,000 yr. ago) were significantly less intense than those of the middle and late Pleistocene. Intensification is worldwide, appearing in both the Pacific and the North and South Atlantic. As a first hypothesis, it might be related to a substantial increase in the volume of the permanent ice cap; but a $1 \% 0 \delta^{18} \mathrm{O}$ increase in oceanic waters would require doubling the size of the ice cap, which seems rather unrealistic. A second hypothesis is that the worldwide increase in oceanic $\delta^{18} \mathrm{O}$ values in the early Pleistocene is related to a decrease in the ice $\delta^{18} \mathrm{O}$ values.

Thus, Stage 22 may not only mark a time of maximal volume of ice sheets but also indicate a time of highly ${ }^{18} \mathrm{O}$-depleted ice. The fact that this stage is also related to an important climatic change is illustrated by the faunal evolution at the same time: highest percentages of Globigerina pachyderma, decrease in Globorotalia inflata percentages, and significant changes in G. truncatulinoides coiling ratios.

\section{CARBON 13 VARIATIONS}

The variations in $\delta^{13} \mathrm{C}$ values of benthic foraminiferal calcite should give an indication of the ages of the deep waters and an indication of sources of NADW (Figs. 2 and 3). Our results for mixed assemblages are most complete; however, the partial curves obtained from monospecific samples display the same general trends: $\delta^{13} \mathrm{C}$ values are higher during glacial episodes. The positive correlation between maximal $\delta^{13} \mathrm{C}$ values and glacial episodes might arise form localized NADW sources in the lower latitudes of the North Atlantic during glacial episodes, or from enrichment in ${ }^{13} \mathrm{C}$ of the total dissolved $\mathrm{CO}_{2}$ of the surface waters that generate NADW. These alternatives are compatible.

The present major source of NADW is the Norwegian Sea, in which an inflow of warm saline surface water is progressively cooled during its transfer towards high latitudes. Reid (1979) showed that a conspicuous part of these saline waters is contributed by the Mediterranean outflow. Values of $\delta^{13} \mathrm{C}$ of benthic calcites (Vergnaud Grazzini, 1981) show that, during glacial stages, the Mediterranean kept on generating its deep waters. On the contrary, during the last glacial stage, the Norwegian Sea could no longer act as a sink for surface waters because a permanent ice cover led to the water mass stratification and because the Norwegian Current had disappeared. We hypothesize that during the last glacial stage NADW sources were located in lower latitudes than today, some $20^{\circ}$ to the south, and that the Mediterranean outflow still contributed part of the saline waters.

Oxygen and carbon isotope analyses of benthic foraminifers from Site 517 show that during Pleistocene glacial cycles, NADW was cooler than today and that the Mediterranean outflow might still have contributed to the NADW sources. An increase in earth's major ice volume probably occurred in the early Pleistocene between the Olduvai and Jaramillo magnetic events in a progressive way and culminated in the time corresponding to Isotopic Stage 22.

\section{PALEOTEMPERATURES IN SURFACE WATERS AND SURFACE CIRCULATION}

The oxygen isotopic composition of planktonic foraminifers is controlled by the temperature and the ${ }^{18} \mathrm{O} /$ ${ }^{16} \mathrm{O}$ ratio of the water in which the foraminifers live. It also depends on depth habitat, maximum temperature variations within the euphotic zone, and dissolution effects. However, the preservation of foraminiferal tests at the water depth at which the cores were raised $(2953$ $\mathrm{m})$ is good. The species analyzed, Globigerinoides ru- 
ber, lives in the near-surface waters and should thus record physicochemical parameters of surficial waters. Similar trends for the middle and late Pleistocene may be recognized for both planktonic and benthic curves; in particular, maximum $\delta^{18} \mathrm{O}$ values start to increase toward $17 \mathrm{~m}$ and reach maximal values in Stage 22 (Fig. 3 ). This increase is around 0.7 to $0.9 \%$ and may correspond to a glacial effect. $\delta^{18} \mathrm{O}$ amplitude variations are also relatively high and average $2 \%$, thus reflecting a glacial effect plus a slight temperature effect.

Stages 12 and 14 are also well marked on planktonic and benthic curves (Figs. 2 and 3), but some discrepancies appear for Stages 8, 10, and 18 and stages older than 30 . Stages 8 and 18 of the planktonic curve correspond to interglacial peaks of the benthic curve; Stage 10 is not marked on the planktonic curve.

\section{Globorotalia truncatulinoides Coiling Ratios and the Brazil Current Influence}

Percentages of right-coiling Globorotalia truncatulinoides in surface sediments are presently related to the southerly flowing Brazil Current (Pujol and Duprat, this volume); present-day percentages are around $40 \%$. Some periods of the Pleistocene are characterized by percentages of right-coiling forms in excess of $40 \%$. Such episodes might have corresponded to a southward penetration of the Brazil Current; they are generally short in duration, with the exception of those corresponding to Isotopic Stages 16,18 , and 19 (shaded areas, Curve B, Fig. 6). The short episodes correspond to Isotopic Stages 7, 9, transition 11-12, 17, and 27; they also correspond to lower $\delta^{18} \mathrm{O}$ values in planktonic foraminifers.

These lower values suggest a warming of surface waters resulting from increased southerly flow of the Brazil Current, but right coiling forms in excess of $40 \%$ also occur during Glacial Stages 16 and 18. Some authors (Wilson, 1966, 1969; Hollin, 1972) have proposed that Antarctic surges periodically transported floating ice to $25^{\circ} \mathrm{S}$. First-order estimates of the heat budget changes within the Antarctic Current system, assuming a melting time of about 50-100 yr., led Flohn (1978) to the conclusion that following an ice surge, the Benguela Current would have increased its intensity by about $30 \%$, and the intensity of the South Equatorial Current might have increased, including its southern branch along the South American continent. Antarctic surges might have caused some rapid southward excursions of the Brazil Current during cold isotopic stages, inducing a southward migration of the right-coiling forms of G. truncatulinoides.

\section{CONCLUSION}

The upper $24 \mathrm{~m}$ of Site 517 contain an expanded record of climatic events during the whole Pleistocene. This period is characterized by a climatic instability that results in more than 14 climatic cycles. These cycles have been identified on the basis of oxygen isotopic analyses of benthic foraminifers. Three episodes can be recognized from the oxygen isotopic curve. Glacial extreme $\delta^{18} \mathrm{O}$ values earlier than 1.6 (or 1.8) Ma were not isotopically heavier than present-day calculated equilibrium

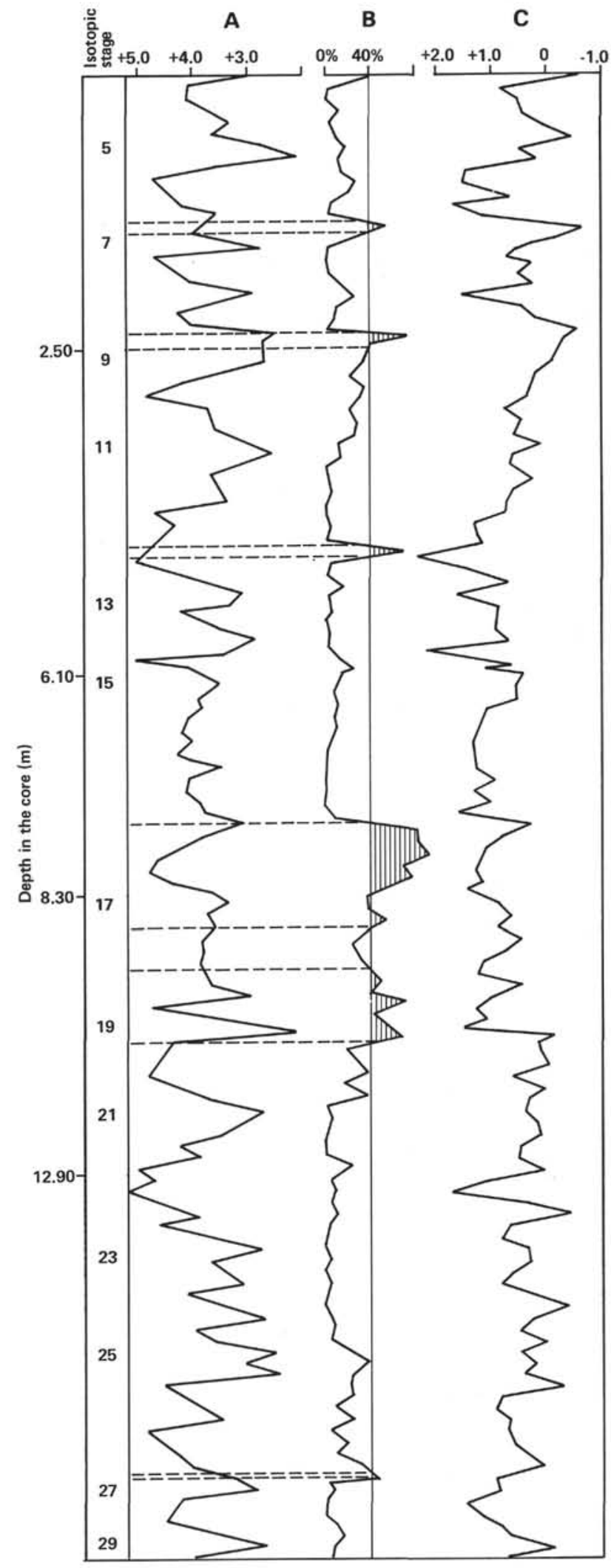

Figure 6. Curve A. Isotopic stratigraphy provided by $\delta^{18} \mathrm{O}$ variations of benthic foraminifers from Figure 2. Curve B. Globorotalia truncatulinoides coiling ratios; southward excursions of the Brazil Current might be indicated by percentages of right-coiling forms higher than present, $40 \%$ (shaded area) (after Pujol and Duprat, this volume). Curve C. Downcore $\delta^{18} \mathrm{O}$ record of Globigerinoides ruber at Hole 517 with time (from Fig. 3). 
values. Between 1.6 and $0.9 \mathrm{Ma}$, glacial extreme $\delta^{18} \mathrm{O}$ values increased progressively to reach values that were $1.5 \%$, heavier than present equilibrium values. During the past 900,000 yr., glacial extreme $\delta^{18} \mathrm{O}$ values remained nearly $1.5 \%$ heavier than today. This last phase might be related to a greater stability in the volume of ice stored in the northern hemisphere.

Oxygen and carbon isotope analyses of benthic foraminifers have also shown that during Pleistocene glacial cycles, NADW was cooler than today and that NADW sources might still have been partly contributed by the Mediterranean outflow. Lastly, oxygen isotope analyses of planktonic foraminifers, compared to changes in coiling ratios of Globorotalia truncatulinoides, suggest that at certain times in the late Pleistocene strong southward excursions of the Brazil Current followed Antarctic surges.

\section{ACKNOWLEDGMENTS}

We warmly thank Marie-José Urrutiaguer and Annick Dindeleux for their contributions to this work. This research was supported by Centre National de la Recherche Scientifique, Grant ERA 604, and Action Thematique Programmée IPOD Grant 4229 to C. Vergnaud Grazzini and M. Grably. We thank S. M. Savin, C. Pierre, R. Létolle, and W. T. Coulbourn for helpful suggestions and a critical review of the manuscript.

\section{REFERENCES}

Belanger, P. E., Curry, W. B., and Matthews, R. K., 1981. Core top evaluation of the paleooceanographic utility of benthic foraminiferal isotopic ratios. Palaeogeogr. Palaeoclimatol. Palaeoecol., 33:205-220.

Berggren, W. A., Burckle, L. H., Cita, M. B., Cooke, H. B. S., Funnell, B. N., Gartner, S., Hays, J. D., Kennett, J. P., Opdyke, N. D., Pastouret, L., Shackleton, N. J., and Takayanagi, Y., 1980. Towards a Quaternary time scale. Quat. Res., 13:277-302.

Boersma, A., and Shackleton, N. J., 1977. Tertiary oxygen and carbon isotope stratigraphy, Site 357 (mid-latitude South Atlantic). In Supko, P. R., Perch-Nielsen, K., et al., Init. Repts. DSDP, 39: Washington (U.S. Govt. Printing Office), 911-924.

Broecker, W. S., 1982. Ocean chemistry during glacial time. Geochim. Cosmochim. Acta, 46:1689-1705.

Broecker, W. S., and van Donk, J., 1970. Insolation changes, ice volume and the ${ }^{18} \mathrm{O}$ record in deep-sea cores. Rev. Geophys. Space Phys., 8(1):169-198.

Craig, H., and Gordon, L. I., 1965. Deuterium and oxygen 18 variations in the ocean and the marine atmosphere. In Tongiorgi, E. (Ed.), Stable Isotopes in Oceanographic Studies and Palaeotemperatures, Spoleto: Pisa (Consiglio Nazionale delle Recherche, Laboratorio de Géologia Nucleare), pp. 9-130.

Dansgaard, W., and Tauber, H., 1969. Glacier oxygen 18 content and Pleistocene ocean temperatures. Science, 166:499-502.

Duplessy, J. C., Lalou, C., and Vinot, A. C., 1970. Differential isotopic fractionation in benthic Foraminifera and palaeotemperatures reassessed. Science, 168:250-251.

Duplessy, J. C., Moyes, J., and Pujol, C., 1980. Deep water formation in the North Atlantic Ocean during the last ice age. Nature, 286:479-482.

Emiliani, C., 1955. Pleistocene temperatures. J. Geol., 63:538-578. 1966. Palaeotemperature analysis of Caribbean cores P6304 8 and P6304-9 and a generalised temperature curve for the last 425,000 years. J. Geol., 74:109-126.

Flohn, H., 1978. Background of a geophysical model of the initiation of the next glaciation. In Gribbin, J. (Ed.), Climatic Changes: New York (Cambridge University Press), pp. 249-265.

Graham, D. W., Corliss, B. H., Bender, M. L., and Keigwin, L. Jr., 1981. Carbon and oxygen isotopic disequilibria of recent deep-sea benthic foraminifera. Mar. Micropaleontol., 6:483-497.

Hollin, J. T., 1972. Interglacial climatic and Antarctic ice surges. Quat. Res., 2:401-408.
Kroopnick, P., 1980. The distribution of ${ }^{13} \mathrm{C}$ in the Atlantic Ocean. Earth Planet. Sci. Lett., 49:469-484.

Ledbetter, M. T., 1979. Fluctuations of Antarctic bottom water velocity in the Vema Channel during the last 160,000 years. Mar. Geol. 33:71-89.

Olausson, E., 1965. Evidence of climatic changes in North Atlantic deep sea cores with remarks on isotopic palaeotemperature analysis. In Sears, M., (Ed.), Progress in Oceanography (Vol. 3): New York (Pergamon Press), 221-252.

Reid, J. L., 1979. On the contribution of the Mediterranean Sea outflow to the Norwegian-Greenland Sea. Deep-Sea Res., 26(11): 1199-1223.

Reid, J. L., Nowlin, W. D., Jr., and Patzert, W. C., 1977. On the characteristics and circulation of the southwestern Atlantic Ocean. $J$. Phys. Oceanogr. 7:62-91.

Shackleton, N. J., 1967. Oxygen isotope analysis and Pleistocene temperatures reassessed. Nature, 215:15-17.

; 1974. Attainment of isotopic equilibrium between ocean water and the benthonic foraminifer genus Uvigerina: isotopic changes in the ocean during the last glacial. Colloq. Int. CNRS, 219:203-210.

1977. Carbon 13 in Uvigerina: tropical rainforest history and the Equatorial Pacific carbonate dissolution cycles. In Andersen, N. R., and Malahoff, A. (Eds.), The Fate of Fossil Fuel $\mathrm{CO}_{2}$ in the Oceans: New York (Plenum Press), pp. 401-427.

Shackleton, N. J., and Cita, M. B., 1979. Oxygen and carbon isotope stratigraphy of benthic foraminifers at Site 397: detailed history of climatic change during the late Neogene. In von Rad, U., Ryan, W. B. F., et al., Init. Repts. DSDP, 47, Pt. 1: Washington (U.S. Govt. Printing Office), 433-445.

Shackleton, N. J., and Opdyke, N. D., 1973. Oxygen isotope and palaeomagnetic stratigraphy of Equatorial Pacific core V28-238: oxygen isotope temperatures and ice volumes on a $10^{5}$ and $10^{6}$ year scale. Quat. Res., 3:39-55.

1976. Oxygen isotope and palaeomagnetic stratigraphy of Equatorial Pacific core V28-239, late Pliocene to latest Pleistocene. In Cline, R. M., and Hays, J. D. (Eds.), Investigation of Late Quaternary Paleoceanography and Paleoclimatology: Boulder, CO (Geol. Soc. Am. Mem.), 145:449-464.

1977. Oxygen isotope and palaeomagnetic evidence for early northern hemisphere glaciation. Nature, 270:216-219.

Shackleton, N. J., and Vincent, E., 1978. Oxygen and carbon isotope studies in recent Foraminifera from the southwest Indian Ocean. Mar. Micropaleontol., 3:1-13.

Shackleton, N. J., Wiseman, J. H. D., and Buckley, H. A., 1973. Nonequilibrium isotopic fractionation between sea-water and planktonic foraminiferal tests. Nature, 242:177-179.

Streeter, S. S., and Shackleton, N. J., 1979. Palercirculation of the deep North Atlantic: 150,000 years record of berithic Foraminifera and oxygen 18. Science, 203:168-171.

van Donk, J., 1976. ${ }^{18} \mathrm{O}$ record of the Atlantic Ocean for the entire Pleistocene epoch. In Cline, R. M., and Hays, D. (Eds.), Investigation of Late Quaternary Palaeoceanography and Palaeoclimatology: Boulder, CO (Geol. Soc. Am. Mem.), 145:147-163.

Vergnaud Grazzini, C., 1973. Etude écologique et isotopique de Foraminifères actuels et fossiles de Méditerranée [doctoral thesis], Paris.

1976. Non equilibrium isotopic compositions of shells of planktonic Foraminifera in the Mediterranean Sea. Palaeogeogr. Palaeoclimatol., Palaeoecol., 20:263-276.

1981. Foraminiferal ${ }^{13} \mathrm{C} /{ }^{12} \mathrm{C}$ variations in the Mediterranean Neogene and their relationships to local hydrodynamism and oceanic circulations. European Colloquium of Geochronology and Isotope Geology VII, Jerusalem. (Abstracts)

Vincent, E., Killingley, J. S., and Berger, W. H., 1981. Stable isotopes in benthic foraminifera from Ontong-Java Plateau, box Cores ERDC 112 and 123. Palaeogeogr. Palaeoclimatol. Palaeoecol., 33: 221-230.

Vinot-Bertouille, A. C., and Duplessy, J. C., 1973. Individual isotopic fractionation of carbon and oxygen in benthic foraminifera. Earth Planet. Sci. Lett. 18:247-252.

Wefer, G., and Berger, W. H., 1980. Stable isotopes in benthic Foraminifera: seasonal variations in large tropical species. Nature, 209:803-805. 
Weyl, P. K., 1968. The role of the oceans in climatic changes: a theory of the ice ages. Meteorol. Monogr., 8(30):37-62.

Williams, D. F., and Ledbetter, M. T., 1979. Chronology of late Bruhnes biostratigraphy and late Cenozoic disconformities in the Vema Channel (South Atlantic). Mar. Micropaleontol., 4:125-136.

Wilson, A. T., 1966. Variation in solar insolation to the south polar region as a trigger which induces instability in the Antarctic ice-sheet. Nature, 220:477-478.
1969. The climatic effects of large scale surges of ice sheets. Can. J. Earth Sci., 6:911-918.

Woodruff, F., Savin, S. M., and Douglas, R. G., 1980. Biological fractionation of oxygen and carbon isotopes by recent benthic foraminifera. Mar. Micropaleontol., 5:3-11.

Date of Initial Receipt: May 11, 1982 
APPENDIX A

Oxygen and Carbon Isotopic Compositions of the Planktonic Foraminifer Globigerinoides ruber in the Quaternary of DSDP Site 517

\begin{tabular}{|c|c|c|c|c|c|c|c|c|}
\hline $\begin{array}{l}\text { Core-section } \\
(\text { level in } \mathrm{cm})\end{array}$ & $\begin{array}{c}\delta^{18} \mathrm{O} \\
(G . \text { ruber })\end{array}$ & $\begin{array}{c}\delta^{13} \mathrm{C} \\
(G . \text { ruber })\end{array}$ & $\begin{array}{l}\text { Core-section } \\
\text { (level in cm) }\end{array}$ & $\begin{array}{c}\delta^{18} \mathrm{O} \\
\text { (G. ruber) }\end{array}$ & $\begin{array}{c}\delta^{13} \mathrm{C} \\
\text { (G. ruber) }\end{array}$ & $\begin{array}{l}\text { Core-section } \\
\text { (level in } \mathrm{cm})\end{array}$ & $\begin{array}{c}\delta^{18} \mathrm{O} \\
(G . \text { ruber })\end{array}$ & $\begin{array}{c}\delta^{13} \mathrm{C} \\
\text { (G. ruber) }\end{array}$ \\
\hline $1-1,3-5$ & -0.30 & +1.13 & 59 & +1.18 & +0.93 & 30 & +0.15 & +1.55 \\
\hline 10 & +0.81 & +1.35 & $4-2,1$ & +1.57 & +1.79 & 40 & +0.39 & +0.99 \\
\hline 20 & +0.50 & +1.06 & 10 & +1.09 & +0.62 & 50 & +1.53 & +1.80 \\
\hline 30 & +0.43 & +1.20 & 20 & +0.81 & +0.81 & 60 & +1.05 & +1.54 \\
\hline 40 & +0.14 & +0.92 & 30 & +1.09 & +0.73 & 70 & +0.39 & +1.47 \\
\hline 50 & -0.29 & +1.05 & 40 & +0.65 & +0.74 & 80 & +0.93 & +1.56 \\
\hline 60 & +0.53 & +1.33 & 50 & +0.88 & +1.00 & 90 & +0.98 & +1.75 \\
\hline 70 & +0.21 & +1.20 & 60 & +1.37 & +0.78 & 100 & +0.55 & +1.69 \\
\hline 80 & +1.44 & +1.08 & 70 & +1.49 & +1.34 & 110 & +0.19 & +1.33 \\
\hline 90 & +1.44 & +0.37 & 90 & +1.14 & +1.13 & 120 & -0.06 & +1.19 \\
\hline 100 & +0.65 & +0.32 & 100 & +1.49 & +0.47 & 130 & +0.32 & +1.20 \\
\hline 110 & +1.73 & +1.22 & 110 & +1.29 & +1.07 & 140 & +0.90 & +1.32 \\
\hline 120 & +1.17 & +0.97 & 120 & +1.70 & +0.75 & 150 & +0.06 & +1.37 \\
\hline 130 & -0.23 & +1.11 & $4-2,1$ & +0.09 & +0.12 & $6-1,50$ & +0.88 & +1.09 \\
\hline 140 & +0.32 & +0.85 & 10 & +0.33 & +0.85 & 80 & +0.92 & +1.45 \\
\hline 150 & +0.60 & +0.84 & 20 & +0.27 & +0.71 & 100 & +0.70 & +1.54 \\
\hline $1-2,8$ & +0.73 & +0.65 & 30 & +0.20 & +0.64 & 110 & +0.83 & +1.13 \\
\hline 10 & +0.23 & +0.72 & 40 & +0.85 & +0.79 & 120 & +0.37 & +1.27 \\
\hline 20 & +0.47 & +0.77 & 50 & +0.23 & +1.03 & 130 & +1.01 & +1.44 \\
\hline 30 & +0.23 & +0.84 & 60 & +0.56 & +1.01 & 140 & +0.87 & +1.23 \\
\hline 40 & +1.59 & +0.75 & 70 & +0.61 & +0.80 & 149 & +0.32 & +1.36 \\
\hline 50 & +0.40 & +0.93 & 80 & +0.41 & +0.29 & $6-2,10$ & +0.70 & +1.10 \\
\hline 60 & +0.21 & +1.07 & 90 & +0.36 & +0.31 & 20 & +0.24 & +0.84 \\
\hline 70 & -0.57 & +0.19 & 100 & +0.67 & +0.72 & 40 & +0.42 & +1.10 \\
\hline 75 & -0.31 & +0.99 & 110 & +0.74 & +1.13 & 50 & +0.88 & +1.09 \\
\hline $2-1,40$ & -0.04 & +0.81 & $4-3,1$ & +0.37 & +0.54 & 60 & +0.82 & +1.31 \\
\hline 50 & +0.25 & +0.65 & 10 & +1.34 & +1.09 & 70 & +0.57 & +1.42 \\
\hline 60 & +0.35 & +0.31 & 20 & +1.91 & +0.40 & 80 & +1.65 & +1.12 \\
\hline 70 & +0.39 & +0.27 & 30 & +0.50 & +0.78 & 100 & +0.86 & +1.43 \\
\hline 80 & +0.73 & +0.51 & 40 & -0.20 & +0.27 & 110 & +1.06 & +0.91 \\
\hline 90 & +0.46 & +0.48 & 50 & +0.93 & +0.96 & 140 & +0.40 & +1.49 \\
\hline 100 & +0.63 & +0.80 & 60 & +1.06 & +1.17 & 143 & +0.41 & +1.09 \\
\hline 110 & +0.17 & +0.60 & 70 & +0.56 & +0.95 & $6-3,2$ & -0.44 & +0.76 \\
\hline 120 & +0.58 & +0.54 & 80 & +0.54 & +1.04 & 30 & +0.12 & +1.26 \\
\hline 130 & +0.62 & +0.11 & 90 & +0.82 & +0.86 & 40 & +0.14 & +0.33 \\
\hline 140 & +0.26 & +0.76 & 100 & +1.03 & +0.95 & 50 & +0.80 & +1.57 \\
\hline 150 & +0.60 & +0.19 & 110 & +0.53 & +1.21 & 60 & +1.04 & +1.44 \\
\hline $2-2,10$ & +0.66 & +1.39 & 120 & -0.10 & +0.87 & 70 & +1.02 & +1.44 \\
\hline 20 & +0.68 & +0.42 & 130 & +0.43 & +1.25 & 80 & +0.27 & +1.17 \\
\hline 30 & +1.32 & +1.57 & 140 & +0.77 & +1.09 & 90 & +0.35 & +1.34 \\
\hline 40 & +1.27 & +1.44 & 149 & +0.28 & +0.96 & $6-3,100$ & +0.45 & +1.27 \\
\hline 50 & +1.10 & +0.50 & $5-1,50$ & +0.72 & +1.30 & 110 & +0.06 & +0.44 \\
\hline 60 & +2.49 & +0.54 & 60 & +0.44 & +0.96 & 120 & +0.35 & +1.05 \\
\hline 70 & +1.39 & +0.93 & 70 & +0.62 & +1.43 & 130 & +0.18 & +0.80 \\
\hline 80 & +0.65 & +1.49 & 80 & -0.09 & +0.89 & $7-1,10$ & +0.72 & +1.15 \\
\hline $2-2,90$ & +1.60 & +1.24 & 90 & +1.02 & +1.06 & 20 & -0.50 & +0.57 \\
\hline 100 & +0.89 & +1.16 & 100 & +1.12 & +0.52 & 60 & -0.56 & +1.18 \\
\hline 120 & +0.97 & +0.77 & 110 & +0.86 & +0.90 & 70 & +0.06 & +1.07 \\
\hline 130 & +0.71 & +1.21 & 120 & +0.96 & +1.25 & 80 & +0.51 & +1.37 \\
\hline 140 & +2.24 & +1.47 & 130 & +0.79 & +1.29 & 90 & +0.09 & +1.23 \\
\hline 150 & +0.60 & +1.27 & 140 & +0.52 & +0.89 & 100 & +0.23 & +1.11 \\
\hline $2-3,44$ & +1.11 & +0.56 & $5-2,10$ & +0.29 & +0.96 & 110 & +0.64 & +1.25 \\
\hline 50 & +0.40 & +1.04 & 20 & +1.13 & +1.97 & $7-2,0$ & +0.27 & +1.17 \\
\hline $3-1,40$ & +0.56 & +0.80 & 30 & +1.05 & +1.09 & 10 & -0.06 & +0.86 \\
\hline 50 & +0.56 & +0.73 & 40 & +1.72 & +1.65 & 20 & +0.26 & +1.17 \\
\hline 60 & +1.09 & +1.74 & 50 & +1.44 & +1.45 & 30 & +0.06 & +0.96 \\
\hline 90 & +1.33 & +1.41 & 60 & +1.06 & +1.28 & 40 & -0.07 & +0.83 \\
\hline 110 & +1.23 & +1.54 & 70 & +0.95 & +1.38 & 60 & -0.23 & +0.80 \\
\hline 120 & +0.94 & +1.42 & 80 & +0.18 & +1.35 & 70 & -0.38 & +0.73 \\
\hline 130 & +1.32 & +1.56 & 90 & +1.01 & +1.36 & 90 & -0.44 & +0.95 \\
\hline 140 & +0.97 & +1.02 & 110 & +0.22 & +1.26 & 100 & +0.32 & +1.21 \\
\hline 143 & +1.52 & +1.20 & 120 & +0.80 & +1.27 & 120 & -0.24 & +1.17 \\
\hline $3-2,10$ & +0.31 & +0.75 & 130 & +0.69 & +1.23 & 130 & -0.41 & +0.65 \\
\hline 20 & +0.83 & +0.65 & 140 & +1.11 & +1.52 & & & \\
\hline 30 & +1.06 & +0.76 & $5-3,10$ & +0.55 & +1.55 & & & \\
\hline 50 & +1.28 & +0.55 & 20 & +0.02 & +1.59 & & & \\
\hline
\end{tabular}


APPENDIX B

Oxygen and Carbon Isotopic Compositions of Benthic Foraminifers in the Quaternary of DSDP Hole 517

\begin{tabular}{|c|c|c|c|c|c|c|c|c|c|c|c|}
\hline $\begin{array}{l}\text { Core-section } \\
\text { (level in cm) }\end{array}$ & Genus & $\delta^{18} \mathrm{O}$ & $\delta^{13} \mathrm{C}$ & $\begin{array}{r}\delta^{18} \mathrm{O} \\
\text { normal } \\
\text { Uvig }\end{array}$ & $\begin{array}{l}\delta^{13} \mathrm{C} \\
\text { ized to } \\
\text { erina }\end{array}$ & $\begin{array}{l}\text { Core-section } \\
\text { (level in } \mathrm{cm})\end{array}$ & Genus & $\delta^{18} \mathrm{O}$ & $\delta^{13} \mathrm{C}$ & $\begin{array}{c}\delta^{18} \mathrm{O} \\
\text { normali } \\
\text { Uvige }\end{array}$ & $\begin{array}{l}\delta^{13} \mathrm{C} \\
\text { ized to } \\
\text { erina }\end{array}$ \\
\hline $1-1,3-5$ & Mixed & +2.80 & +0.18 & & & $3-2,10$ & \multirow{6}{*}{ Mixed } & +3.08 & +0.44 & & \\
\hline 10 & Pyrgo & +4.57 & +0.90 & +4.07 & 0.00 & 20 & & +3.82 & +0.29 & & \\
\hline 20 & Mixed & +4.10 & +0.30 & & & 30 & & +4.37 & -2.17 & & \\
\hline 30 & Cibicides & +3.18 & +0.80 & +3.80 & -0.10 & 40 & & +4.58 & +0.29 & & \\
\hline 40 & Mixed & +3.43 & +0.55 & & & 50 & & +4.74 & +0.15 & & \\
\hline 50 & Mixed & +3.63 & +0.46 & & & 60 & & +4.45 & +0.40 & & \\
\hline 60 & Planulina & +2.01 & -0.04 & +2.65 & -0.94 & $4-1,1$ & Planulina & +3.00 & +0.54 & +3.64 & -0.36 \\
\hline 70 & Mixed & +2.13 & +0.03 & & & 10 & Planulina & +2.61 & +0.10 & +3.25 & -0.80 \\
\hline 80 & Mixed & +3.67 & +1.09 & & & 20 & Planulina & +3.10 & & +3.74 & - \\
\hline 90 & Mixed & +4.68 & +0.79 & & & 30 & Planulina & +2.97 & +0.65 & +3.61 & -0.25 \\
\hline \multirow[t]{2}{*}{110} & Pyrgo & +4.47 & +0.97 & +3.97 & +0.07 & \multirow[t]{2}{*}{40} & Planulina & +3.21 & \multirow[t]{2}{*}{-0.15} & +3.85 & \multirow[t]{3}{*}{-1.05} \\
\hline & Planulina & +4.01 & +1.02 & +4.65 & +0.12 & & Mixed & +3.40 & & +3.40 & \\
\hline 130 & Mixed & +3.50 & +0.52 & & & 50 & Mixed & +3.81 & +0.16 & & \\
\hline 140 & Mixed & +4.08 & +0.74 & & & \multirow[t]{2}{*}{60} & Pyrgo & +4.30 & +1.31 & +3.80 & +0.41 \\
\hline 150 & Pyrgo & +3.17 & -0.31 & +2.67 & -1.21 & & Planulina & +3.22 & 0.00 & +3.86 & -0.90 \\
\hline \multirow{2}{*}{$\begin{aligned} & 1-2, 8 \\
& 30 \\
& 40\end{aligned}$} & Mixed & +4.64 & +0.76 & & & \multirow{2}{*}{80} & Pyrgo & +4.50 & +0.77 & +4.00 & -0.13 \\
\hline & Pyrgo & +4.55 & +0.47 & +4.05 & -0.43 & & Cibicides & +3.00 & +0.54 & +3.64 & -0.36 \\
\hline \multirow[t]{2}{*}{40} & Pyrgo & +2.88 & -0.23 & +2.38 & -1.13 & 90 & Mixed & +2.90 & +1.02 & & \\
\hline & Planulina & +2.22 & -0.15 & +2.86 & -1.05 & 100 & Planulina & +4.73 & +0.81 & +4.77 & -0.09 \\
\hline 60 & & +4.28 & +0.43 & & & 110 & Planulina & +2.65 & -0.92 & +3.29 & $-1.82 ?$ \\
\hline 70 & & +4.07 & +1.08 & & & 120 & Planulina & +1.46 & -0.62 & +2.10 & $-1.52 ?$ \\
\hline 75 & Mixed & +2.57 & -0.08 & & & $4-2,1$ & Mixed & +2.70 & -0.41 & & \\
\hline 80 & & +2.83 & -0.75 & & & 10 & Mixed & +4.37 & +0.38 & & \\
\hline $2-1,40$ & Pyrgo & +3.18 & +0.38 & +2.68 & -0.52 & 20 & Uvigerina & +4.49 & -0.15 & & \\
\hline \multirow[t]{3}{*}{50} & Planulina & +3.04 & +0.40 & +3.68 & -0.50 & 40 & & +4.83 & -0.41 & & \\
\hline & Pyrgo & +4.51 & +0.83 & +4.01 & -0.07 & 60 & & +3.67 & +0.05 & & \\
\hline & Uvigerina & +3.45 & -0.67 & +3.45 & -0.67 & 70 & Mixed & +2.76 & +0.04 & & \\
\hline 60 & Pyrgo & +4.85 & +0.85 & +4.35 & -0.05 & 90 & & +3.56 & +0.81 & & \\
\hline 70 & Cibicides & +4.18 & -0.25 & +4.82 & -1.15 & 100 ) & & +4.37 & +0.66 & & \\
\hline 80 & Cibicides & +3.36 & +0.18 & +4.00 & -0.77 & $4-3,1$ & & +3.83 & -0.26 & & \\
\hline & Uvigerina & +3.42 & +0.41 & & & 10 & & +5.00 & +0.04 & & \\
\hline 100 & Cibicides & +2.95 & +0.46 & +3.59 & -0.44 & 20 & & +4.64 & +0.04 & & \\
\hline 110 & Cibicides & +2.39 & +0.09 & +3.03 & -0.81 & 30 & & +5.25 & +0.32 & & \\
\hline & Pyrgo & +3.27 & +1.14 & +2.77 & +0.24 & 40 & & +4.61 & +0.34 & & \\
\hline 120 & Pyrgo & +3.03 & +0.56 & +2.53 & -0.34 & 50 & & +3.93 & -0.32 & & \\
\hline 140 & Planulina & +2.70 & -0.54 & +3.34 & -1.44 & 60 & & +4.64 & +0.76 & & \\
\hline & Pyrgo & +4.39 & & +3.89 & - & 70 & Mixed & +2.25 & - & & \\
\hline $2-2,10$ & Planulina & +2.73 & +0.16 & +3.37 & -0.74 & 80 & Mixed & +2.79 & +0.07 & & \\
\hline 20 & Planulina & +3.97 & +0.30 & +4.61 & -0.60 & 90 & & +3.75 & +0.79 & & \\
\hline 30 & Mixed & +4.32 & +1.33 & & & 110 & & +3.10 & +0.16 & & \\
\hline 60 & Mixed & +5.04 & +1.40 & & & 120 & & +4.17 & +0.20 & & \\
\hline 70 & Mixed & +4.45 & +0.30 & & & 140 & & +2.75 & -0.52 & & \\
\hline 90 & Uvigerina & +3.00 & -1.00 & & & 149 & & +3.05 & - & & \\
\hline & Planulina & +2.54 & -0.23 & +3.18 & -1.13 & $5-1,50$ & & +3.66 & +0.90 & & \\
\hline 100 & Cassidulina & +3.25 & -0.53 & & & 60 & & +2.55 & +0.05 & & \\
\hline 110 & Planulina & +3.69 & +0.57 & +4.33 & -0.33 & 70 & & +3.12 & +0.97 & & \\
\hline & Uvigerina & +4.10 & +0.08 & & & 80 & Mixed & +2.55 & +0.33 & & \\
\hline 120 & Uvigerina & +3.57 & -0.25 & & & 90 & Mixed & +4.56 & +0.03 & & \\
\hline 130 & Uvigerina & +2.88 & -0.40 & & & 120 & & +3.57 & +0.16 & & \\
\hline 140 & Uvigerina & 3.41 & -1.09 & & & 130 & & +4.86 & - & & \\
\hline & Cibicides & +2.78 & -0.07 & +3.42 & -0.97 & 150 & & +4.22 & +0.12 & & \\
\hline 150 & Pyrgo & +5.67 & & +5.17 & - & $5-2,10$ & & +4.02 & -0.44 & & \\
\hline $2-3,44$ & Mixed & +4.13 & +1.07 & & & 20 & & +3.26 & +2.00 & & \\
\hline 50 & Mixed & +4.00 & +0.59 & & & 30 & & +2.90 & +0.50 & & \\
\hline $3-1,40$ & Mixed & +3.45 & +0.39 & & & 40 & & +4.21 & +1.85 & & \\
\hline 50 & Mixed & +3.78 & +0.77 & & & 60 & & +4.58 & +0.84 & & \\
\hline 60 & Planulina & +3.15 & +0.11 & +3.79 & -0.79 & 70 & Mixed & +3.72 & +0.56 & & \\
\hline 70 & Mixed & +4.08 & +0.63 & & & 80 & & +2.77 & +1.01 & & \\
\hline 80 & Planulina & +3.57 & +0.50 & +4.21 & -0.40 & 90 & & +4.01 & +0.08 & & \\
\hline 90 & & +4.00 & +0.14 & & & 110 & & +3.16 & +0.03 & & \\
\hline 100 & & +4.28 & +0.79 & & & 120 & & +3.32 & -0.45 & & \\
\hline 110 & & +3.47 & +0.63 & & & 140 & & +2.96 & -0.39 & & \\
\hline 120 & Mixed & +4.19 & +1.01 & & & $5-3,10$ & & +3.42 & +1.36 & & \\
\hline 130 & & +4.15 & +0.49 & & & 50 & & +3.50 & -0.37 & & \\
\hline 140 & & +3.94 & +1.03 & & & 60 & Mixed & +3.28 & +0.80 & & \\
\hline 149 & & +3.78 & +0.11 & & & $100)$ & & +3.86 & +0.84 & & \\
\hline
\end{tabular}


C. VERGNAUD GRAZZINI, M. GRABLY, C. PUJOL, J. DUPRAT

Appendix B. (Continued).

\begin{tabular}{|c|c|c|c|c|c|c|c|c|c|c|c|}
\hline \multirow{3}{*}{$\begin{array}{r}\begin{array}{r}\text { Core-section } \\
(\text { level in cm) }\end{array} \\
5-3, \begin{array}{l}110 \\
120\end{array}\end{array}$} & Genus & \multirow{3}{*}{$\begin{array}{l}\delta^{18} \mathrm{O} \\
+2.32 \\
+3.51\end{array}$} & \multirow{2}{*}{$\frac{\delta^{13} \mathrm{C}}{+1.46}$} & \multicolumn{2}{|c|}{$\begin{array}{c}\delta^{18} \mathrm{O} \quad \delta^{13} \mathrm{C} \\
\text { normalized to } \\
\text { Uvigerina }\end{array}$} & \multirow{2}{*}{$\begin{array}{c}\begin{array}{c}\text { Core-section } \\
\text { (level in cm) }\end{array} \\
60\end{array}$} & \multirow{3}{*}{$\begin{array}{c}\text { Genus } \\
\text { Planulina } \\
\text { Planulina }\end{array}$} & \multirow{3}{*}{$\begin{array}{l}\delta^{18} \mathrm{O} \\
+1.89 \\
+1.81\end{array}$} & \multirow{3}{*}{$\begin{array}{l}\delta^{13} \mathrm{C} \\
-0.35 \\
+0.29\end{array}$} & \multicolumn{2}{|c|}{$\begin{array}{c}\delta^{18} \mathrm{O} \delta^{13} \mathrm{C} \\
\text { normalized to } \\
\text { Uvigerina }\end{array}$} \\
\hline & & & & & & & & & & +2.53 & -0.55 \\
\hline & & & +0.73 & & & 70 & & & & +2.45 & -0.60 \\
\hline 130 & Mixed & +3.22 & +0.38 & & & $6-3,80$ & Mixed species & +3.08 & +1.11 & & \\
\hline 140 & & +2.49 & +0.02 & & & 90 & Planulina & +2.12 & -0.34 & +2.76 & -1.24 \\
\hline 150 & & +2.36 & +0.11 & & & 100 & Planulina & +2.77 & +0.49 & +3.41 & -0.41 \\
\hline $6-1,50$ & Uvigerina & +1.93 & -2.53 & & & 140 & Uvigerina & +2.83 & -1.28 & & \\
\hline 80 & Planulina & +1.54 & -0.69 & +2.18 & -1.59 & $7-1,50$ & Planulina & +2.56 & +0.48 & +3.20 & -0.42 \\
\hline 110 & Mixed & +2.55 & +0.01 & & & 80 & & +2.99 & +1.92 & & \\
\hline 120 & Mixed & +4.20 & -0.03 & & & 90 & & +2.62 & +0.71 & & \\
\hline 150 & Planulina & +3.39 & +0.85 & +4.03 & -0.05 & 100 & Mixed & +2.42 & +1.34 & & \\
\hline $6-2,10$ & Planulina & +1.92 & +0.10 & +2.56 & -0.80 & 110 & & +3.56 & -0.65 & & \\
\hline 20 & Planulina & +2.82 & -0.42 & +3.46 & -1.32 & 130 & & +4.53 & -0.14 & & \\
\hline 30 & Planulina & +3.02 & +0.93 & +3.66 & +0.03 & $7-2,10$ & Mixed & +2.70 & -0.49 & & \\
\hline 40 & Uvigerina & +4.00 & -0.49 & & & 30 & Pyrgo & +3.03 & +1.36 & +2.53 & +0.46 \\
\hline 50 & Planulina & & +1.23 & & +0.33 & 40 & Planulina & +2.92 & +1.44 & +3.56 & +0.54 \\
\hline 60 & Mixed & +3.51 & & +0.34 & & 50 & Planulina & +2.56 & +0.48 & +3.20 & -0.42 \\
\hline 70 & Pyrgo sp. & +3.77 & & & & 80 & Planulina & +1.47 & -0.33 & +2.11 & -1.23 \\
\hline 100 & Mixed & +3.88 & +0.63 & & & 100 & Mixed & +2.99 & -0.13 & & \\
\hline 120 & Planulina & +2.30 & -0.12 & +2.94 & -1.02 & $7-3,20$ & Mixed & +4.06 & 00 & & \\
\hline 130 & Planulina & +2.36 & +0.14 & +3.00 & -0.76 & 30 & Mixed & +3.04 & +0.57 & & \\
\hline 150 & Mixed & +2.17 & 0.00 & & & 40 & Mixed & +3.08 & +0.82 & & \\
\hline $\begin{array}{r}6-3,20 \\
50\end{array}$ & $\begin{array}{l}\text { Planulina } \\
\text { Mixed }\end{array}$ & $\begin{array}{l}+2.82 \\
+4.07\end{array}$ & $\begin{array}{l}-0.42 \\
+0.28\end{array}$ & +3.46 & -1.32 & 90 & Pyrgo & +4.17 & +1.40 & +3.67 & +0.50 \\
\hline
\end{tabular}

Note: A blank in the $\delta^{18} \mathrm{O}$ column means no result; mixed species analyses have blanks in the normalized columns because a single correction factor cannot be applied. 